\title{
ANALYSIS OF ALTERNATIVE TRANSPORTATION IN REMOTE AREAS BY USING THE GRAVITY METHOD
}

\author{
Amelia Paulina ${ }^{1}$, Yuda Yulianto ${ }^{2}$, Alti $^{3}$ \\ 1. STMT Trisakti, 2. STMT Trisakti, 3. STMT Trisakti \\ corresponding author : paulina.amelia09@gmail.com
}

\begin{abstract}
The spread of the distribution of goods and services is a necessity in the development of a country or region. It is in line with the principle of distribution i.e. the manufacturer wants to spread stuff covering - breadth, on the other hand consumers want ease in obtaining the goods. Development of the remote area is the responsibility of the government to empower and build the area. In writing this, we try to recommend alternative transportation to propose in remote areas by connecting the two cities using the method of gravity.

Keywords: the theory of gravity, cable car, distribution of goods, transport, prices of goods
\end{abstract}

\section{Introduction}

Recently, President Joko Widodo was being heavily - concern in making and realization of distribution program of goods throughout the city in Indonesia. According to him, development is not fully equitable to all corners of the Land so that the distribution of goods that are in Indonesia have not been spread well throughout the cities in Indonesia. Many programs that are currently on his progress to achieve this in the Eastern and Western regions of Indonesia that does its infrastructure is still lacking. One of them is the region of Irian Jaya.

Irian Jaya is one of the provinces in Indonesia that still has a problem in terms of the distribution of goods. It is caused by many factors, one of the problem is because of the limited mode of transportation. The needed for a new mode of transportation to unravel the problem of distribution in the region. Especially considering the price of goods in the cities that existed in Irian Jaya still varied and quite high caused by the limitations of the mode of transportation and accessibility which is owned the region.

For example, for the cities in Irian Jaya such as Wamena that has a fairly high prices for staple goods. The high prices of the staple ingredients in the city led to the advancement of the economy of the city quite a lag compared to other cities - cities existed in Indonesia. Only the availability 
of airports to distribute goods in the region is one of the causes. Based on the data obtained by the author, per kilogram, in Wamena, the price of cement/sak Rp 1 million - 2 million,-, in Jayapura, Rp 70,000,-, in Nabire, Rp 85,000,-, in Agats, Rp 2 million,-, in Sarmi, Rp 1.5 million. (source: Detik Finance, August 2017). While the average price of one sack of cement in Makassar is Rp 42,000 (source: Makassar Tribunnews, January 2017).

While the current delivery of the goods using the landline in Indonesia remained the favorite mode chosen by the Supplier to distribute the goods get to the hands of the consumer (end consumer).

So, in this occasion the author wanted to examine about the level of interactions between cities in Papua Province to the town of Wamena as the observed area and the city of Agats, Timika, Jayapura, Nabire and Sarmi, as supporters to do the distribution of goods, with the orientation of the expected by the existence of a cheap ground transportation prices of staple goods will primarily have a value that is not high as it is now. Wamena is the capital of Jayawjaya County and has many natural riches can often we use, but the geographical location of the city is becoming a problem, so the author will examine the relationship of interaction Wamena city cities who has access to the sea with the gravity method. The author chose the city of Agats, Timika, Jayapura, Nabire and Sarmi, because the city - the city has a Seaport and an airport that can be used to distribute the goods - goods sent from Wamena to the city - another city that exists in Indonesia and as well as vice versa.

The author is planning to use the cable mode of transportation as an alternative to transport because of natural conditions in Papua.

Given the large number of developments can be found in this issue, it is necessary the existence of limitations problems that are clear about what made and resolved in this paper. As for the limitations problem in this research are as follows :

1. Use of the theory to connecting two cities with Newton Gravitational model that developed by Stewart. 
2. Make public transportation directly between these two points/city in a straight line.

3. The research was oriented on the equitable distribution of goods without/haven't seen from the point of view of investments by investors (Return of Investment)

Authors realize there are still many deficiencies in writing this due to the limitations in terms of data and relative short time. Hopefully this article can inspire other parties especially government in terms of accelerating the spread of the distribution of goods in the region, particularly remote areas and minimal choice mode of transportation.

\section{The Theory of Gravity}

The approach can be used to see or assess relations between regions is the gravity Model. In this model, the area is considered a mass. The relationship between the area identified with relationships between masses. The region also has mass appeal, so influential between the region as a manifestation of the power of attraction between regions. Due to this fact then the gravity model can be applied as one model analysis. The gravity model is drawn from the concept of physics that States the power of attraction between two poles of a magnet. In the analysis of the region, the grouping of the population, the concentration of activities, or potential natural resources, is considered to have an attraction which can be analogized with magnetic attraction.

The weakness of this model in the analysis of the region mainly lies in the variable that is used as a measure. In physics, each molecule of a substance having the properties of homogeneous, but that is not the case the element (which is analogous with the molecules of a substance) forming an area, such as elements of the population. To cover this weakness of the gravity model has been widely developed by including not only the variables mass, but also the social symptoms as a factor called the "weights". 
In the gravity model, analogous to the area as a mass. The mass is formed in accordance with the principles that determine the overall shape (Isard, 1969). As a simple illustration is the following.

A region $\mathrm{X}$ is divided into several sub areas. The population of region $\mathrm{X}$, equal to $\mathrm{P}$. The number of trips undertaken resident $\mathrm{X}$ is $\mathrm{T}$. Differences within each sub region (revenue, division of population based on age, and others) are ignored.

Regional Division of $\mathrm{X}$ into sub areas $\mathrm{i}, \mathrm{j}, \mathrm{k}$ and so on are adjusted with the interest of the analysis. The number of trips that start from sub areas $\mathrm{i}$ and ended up in the sub region $\mathrm{j}$, in the theory or hypothetical is $\mathrm{Pj} / \mathrm{P}$ (distance, time and costs are ignored). The average number of trips undertaken by each individual who represents the region is $\mathrm{T} / \mathrm{P}=\mathrm{k}$ (i.e. number of trips on average each individual user). So the number of journeys made by individuals who end up in $\mathrm{j}$ is $\mathrm{k}$. $\mathrm{PJ} / \mathrm{P}$ per individual. If the $\mathrm{Pi}$ is the population of sub areas $i$, amount of travel in theory committed residents of sub areas $\mathrm{i}$ to $\mathrm{j}$ is:

$T_{i j}=\frac{P_{i} \cdot P_{j}}{P}$, this is called hypothetical travel.

$\mathrm{T}_{\mathrm{ij}} \quad=$ Number of Trips from Sub area $\mathrm{i}$ to Sub area $\mathrm{j}$

If the number of trips from I to $\mathrm{j}$ is known to be $\mathrm{I}_{\mathrm{ij}}$ (obtained from the survey result), and the distance from $i$ to $j$ is $d_{i j}$, then from the three factors mentioned above $-\mathrm{I}_{\mathrm{ij}}, \mathrm{T}_{\mathrm{ij}}$ and $\mathrm{d}_{\mathrm{ij}}-\mathrm{a}$ functional relation in a form of mathematical model can be derived. This relation is obtained by finding the functional relation between $\mathrm{I}_{\mathrm{ij}} / \mathrm{T}_{\mathrm{ij}}$ and $\mathrm{d}_{\mathrm{ij}}$ - which is compiled in a cartesius axis. The vertical axis is $\log \left(\mathrm{I}_{\mathrm{ij}} / \mathrm{T}_{\mathrm{ij}}\right)$, while the horizontal axis is $\mathrm{d}_{\mathrm{ij}}$.

A relation is acquired out of this linear regression equation:

$\log \left(\mathrm{I}_{\mathrm{ij}} / \mathrm{T}_{\mathrm{ij}}\right)=\mathrm{a}-\mathrm{b} \cdot \log \mathrm{d}_{\mathrm{ij}}$

If $\mathrm{a}=\log \mathrm{c}$, then $\log \left(\mathrm{I}_{\mathrm{ij}} / \mathrm{T}_{\mathrm{ij}}\right)=\log \mathrm{c}-\mathrm{b} \cdot \log \mathrm{d}_{\mathrm{ij}}$

$\mathrm{I}_{\mathrm{ij}} / \mathrm{T}_{\mathrm{ij}}=\mathrm{c} /\left(\mathrm{d}_{\mathrm{ij}}\right)^{\mathrm{b}}$ becomes $\mathrm{I}_{\mathrm{ij}}=\left(\mathrm{c} \cdot \mathrm{T}_{\mathrm{ij}}\right) /\left(\mathrm{d}_{\mathrm{ij}}\right)^{\mathrm{b}}$

$I_{i j}=\frac{C \cdot k \cdot P_{i} \cdot P_{j}}{P \cdot\left(d_{i j}\right)^{b}}$ if $(c \cdot k) / p=G$ 
Hence: $I_{i j}=G \cdot \frac{P_{i} \cdot P}{\left(d_{i j}\right)^{b}}$

Application of this gravitational for the interest of regional analysis requires us to pay attention to some issues that arise. The first problem is the measurement of the variable of the mass and distance. Based on experience, the measurement of the mass is taken in various ways. In the next formulation, the mass used as a measurement is the population size. Yet, in the study of the metropolitan migration, the number of workforce or regional income is more appropriate to be used as a measurement of the mass rather than the size of the population. If marketing issues are to be examined, then the amount of cash flow is more appropriate to be used as the measurement.

The distance can be measured in several ways. The specified distance is the geographical distance. Another way of stating the distance is with the unit of time, e.g. when the traffic is analyzed in metropolitan cities. If industrial location issues were to be analyzed, then the unit of transportation fare will be more appropriate to determine as the size of the distance. Just like the size or unit of mass, the size or unit of distance used depends on the issue to be analyzed, the available data, and the objective of the study. Other measurements that may be used as the unit of distance are the use of fuel, the number of gear turnover or stops, and the amount of influence various opportunities, and other forms of "social distance" (Isard, 1969). Another basic problem is the "weight" given to the mass. In the formula of Iij = G $\left(\mathrm{P}_{\mathrm{i}} . \mathrm{P}_{\mathrm{j}}\right) /\left(\mathrm{d}_{\mathrm{ij}}\right)^{\mathrm{b}}$, the mass is considered homogeneous, while it is not considered so in reality. Elements in the sub area $i$ are not the same as the elements in the sub area $j$; therefore, different weight should be given for the sub area $i$ and $\mathrm{j}$ should be done. As an example, the weight which can be used is the average income per capita in each of the sub area. One of the ways to perfect the gravitational model formula is using mass with weight so that the gravitational model will be: 
$I_{i j}=G \cdot \frac{\left(w_{i} \cdot P_{i}\right) \cdot\left(w_{j} \cdot P_{j}\right)}{\left(d_{i j}\right)^{b}}$, when $b=2$, the interaction is called demographical force

$\mathrm{W}_{\mathrm{i}}$ and $\mathrm{w}_{\mathrm{j}}$ is the average income per capita in sub area $\mathrm{i}$ and $\mathrm{j}$. As an example, the use of such weight of the revenue is when the volume of traffic of the high-income class is analyzed. In addition, the level of education or the size of an average family can also be used as the weight.

The Principle of Distribution of Goods

In the effort to streamline the flow of goods or services from the producers and the consumers, an important factor that should not be overlooked is choosing the proper distribution channel (M. Fuad:2006). The understanding of the proper distribution channel in a business is needed. Distribution channel is the channel used by the producers to distribute the products to the consumers or various activities of companies in trying so that the products are received by the consumers.

In the discussion of the distribution channel, there are two poles that are often discussed: the Principles Pole and the Consumer Pole. The producer/principle pole is how to widely distribute the products. The consumer pole is how they obtain the products with ease.

This shows that the opening of a new channel will ease the distribution of goods in the Papua area which later will have a direct impact upon the price of goods in the destination city.

\section{Cable-Car Transport}

One of the factors which causes the high price of goods that exists in Papua is the lack of transportation in Papua. Mode of transportation that currently exists is only limited to air traffic, while shipping via air has a maximum limit for loading goods and considerable costs in a single shipment. Each mode of transportation has its own service characteristics that allow the goods (or passengers) to move to any other mode that exists 
for one trip from the origin to destination. Therefore, the author has an idea to provide cable-cars as a new mode of transportation in Papua. This transportation mode is chosen by the author because the delivery of the goods with this mode is considered quite efficient compared to constructing roads.

Cable-car transport system effectively does not exist in an urban and suburban landscape of public transport in the cities of Indonesia. France itself implements the cable-car mode of transportation for skiers in the winter sports resort. The cable-car is largely aimed at the tourist market. Several metropolitan areas even include cable-car into their public transportation network.

The cable cars are categorized into 2 :

1. Aerial Tramway

It is a cable transport system with one or two vehicles which go back and forth on a steady course. The vehicle is generally large which varies between 30 and 200 passengers.

2. The Gondola Lift

It is a system that is equipped with a moving cabin along a one-direction circle. The gondola lift cabins are relatively small only accommodating 4 to 40 passengers.

The technology used is different depending on the cable and its function:

1. Monocable is a technology using one of the cables to launch and support the weight of the cable. This type of technology limits the distance between poles about 600 to 800 meters.

2. Bicable or tricable is a technology that uses one of the cables used to run and one or two of the other to hold its load. This type of technology allows a greater distance between the poles i.e. up to several kilometres.

Furthermore, according to Clement-Werny at al. (2011), the cost needed to make monocable gondola in mountainous area is as follows:

- $\quad$ Drive station : 3,000,000 euro

- Intermediate station $\quad: 1,500,000$ euro

- Return station : : $1,000,000$ euro 
- Cabin

- Pylon
: 30,000 euro

: 100,000 euro

Then some work of the cable-car that has been carried out on the next mountainous location can be summed up on the price of each of its items by CETE of Lyon manufacturers.

Figure 1 Price Elements Of The Cable Car Mountain Area

\begin{tabular}{|l|c|c|}
\hline \multicolumn{1}{|c|}{ System } & Monocable & Tricable \\
\hline Drive station & 2,5 to 3 Million Euro & 4 to 5 Million Euro \\
\hline Intermediete station & 1,2 to 1,5 Million Euro & - \\
\hline Return station & 1 Million Euro & 3 to 4 Million Euro \\
\hline 8 to 10 seats cabin & 30,000 Euro & - \\
\hline 35 seats cabin & - & 300,000 Euro \\
\hline 100 seats cabin & - & 1 Million Euro \\
\hline Pylon & 100,000 Euro & 500,000 Euro \\
\hline
\end{tabular}

Source: CETE of Lyon, manufacturers

\section{Method}

The basic method used in this research is descriptive method. According to Nazir (1988:63) in the Book of Research Method Examples, descriptive method is a method in researching the status of a group of humans, an object, a set of conditions, a system of thinking or a class of current events. The purpose of this descriptive research is to make a description systematically, factually and accurately regarding the facts, properties and relations between phenomena which are analyzed. Descriptive method also wants to study the norms or standards; therefore, this descriptive research is also known as a normative survey. In the descriptive method normative issues can be examined together with the issues of status and simultaneously make a comparison between phenomena. Such studies are generally called as descriptive studies or research. The perspective of the range of time in a descriptive research is the present, or at least the period of time which is still in the memory of respondents.

Population and Sample

The population is within the territory of generalization which consists of: the object/subject who has certain qualities and characteristics set by the 
researchers to be studied and then drawn conclusion out of them (Sugiyono,2011:80).

The population in this research is the number of population in cities and also districts, PDRB ADHB (Gross Regional Domestic Product on The Basis of The Existing Prices) of the cities/counties whose data are obtained from BPS (Central Bureau of Statistics), the price of basic daily needs in Papua, and also the price of cable-car elements.

According Sugiyono, the sample is part or a number of and characteristics owned by the population. If the population is large and researchers may not learn all within the population - e.g. because of lack of funds, manpower and time - then researchers take samples of out of the population. What is studied out of the sample, a conclusion will be put in place for the population. Therefore, the samples taken from a population must be representative (Sugiyono, 2011).

Therefore, the samples of this research are the PDRB ADHB of the cities/districts in the year of 2016, the population of the cities/counties as per 2016, the latest price of the daily needs from the online and offline news channels, as well as the price of the cable-car elements of CETE manufacturers. Variables in this research are population, PDRB AHDB, distance, price of goods, the needs for the cable-car elements. This research data collection method using several ways including interview asking questions online through one of the online chatting platform and collecting data online through BPS website from each region.

Data Analysis Method

\section{Analysis of The Interactions Between Cities}

This research uses a gravitational analysis to see the size on the value of interaction between cities through the gravitational theory proposed by Newton. Then, the theory is developed by some geographers, such as Stewart and also floorplan expert Robinson Tarigan by replacing mass in the gravitational equation with a variable which reflects more about the interaction between cities, such as population. Next, the variable of mass that has been replaced by population is added "weight" which in this case 
can vary depending on the relation of interaction in the sector that we will we estimate. Because this time the research focuses more on equal distribution which is one of the economic aspects, the weight used is the value of the PDRB of the related cities/counties.

The gravitational formula that has been developed by Stewart is as follows: $I_{i j}=G \cdot \frac{\left(w_{i} \cdot P_{i}\right) \cdot\left(w_{j} \cdot P_{j}\right)}{\left(d_{i j}\right)^{b}}$

If value of $\mathrm{I}_{\mathrm{ij}}$ gets larger, then it indicates that the value of the interaction between region $\mathrm{i}$ to $\mathrm{j}$ is getting larger. Then, it can be concluded that there will be a lot more interaction from population $i$ to $j$ if there is an alternative mode of transportation to connect both cities.

2. The Analysis of The Principle of Distribution of Goods

The principle of distribution of goods will be used in this research to review the magnitude of the effect on distribution of price of goods in the cities that can be incurred from the existence of an alternative mode of transportation. We will look at the impact that will be received directly by the two parties: either from the principle side or the consumer side. These principles which are taken from a variety of sources is expected to give more description to the readers about this research.

\section{Analysis of Cable-Car Transport}

Analysis on cable-car transportation is only limited to the level of the needs of each element and the amount of money needed to develop the cable-car transportation route from related cities. This time the research plans that the cable-car will be allocated to distribution channel of goods where the weight of load which should be transported by the cable car is a 20' container or equivalent to $500 \mathrm{~kg}$, which then the $500 \mathrm{~kg}$ weight is assumed to a number of 10 passengers assuming 1 passenger have a weight of $50 \mathrm{~kg}$. Then, once it is known which city we plan for, we are able to measure the distance by making a straight line from the center of the city to the center of another city. Next, we will 
identify the route that will be passed by, so that we can estimate the suitable type of cable and how many poles are needed, because the type of the cable itself will influence the distance between pillars that will be used.

\section{Discussion and Result}

The determination of the value of interaction between the two cities is achieved by using the calculation of interaction of two cities with Newton's Gravitational Model developed by Stewart and then generating an equation as follows:

$I_{i j}=G \cdot \frac{\left(w_{i \cdot} P_{i}\right) \cdot\left(w_{j} \cdot P_{j}\right)}{\left(d_{i j}\right)^{b}}$

Description:

$\mathrm{I}_{\mathrm{ij}} \quad$ : The strength of the interaction region

$\mathrm{G}$ : The number of empirical constants, the value is 1

$\mathrm{P}_{\mathrm{i}} \quad$ : The number of population of the region $\mathrm{i}$

$\mathrm{P}_{\mathrm{j}} \quad$ : The number of population of the region $\mathrm{j}$

$\mathrm{W}_{\mathrm{i}}$ : The weighting variable area $\mathrm{i}$ (income per capita)

$\mathrm{w}_{\mathrm{j}} \quad$ : The weighting variable area $\mathrm{j}$ (income per capita)

$\mathrm{d}_{\mathrm{ij}} \quad$ : The distance of the region $\mathrm{i}$ and region $\mathrm{j}$

Wamena - Agats: $\quad \mathrm{I}_{\mathrm{W} . \mathrm{A}}=\frac{(6,11 \cdot 40,116) \cdot(1,82 \cdot 14,412)}{190^{2}}=178,093$

Wamena - Timika: $\quad \mathrm{I}_{\mathrm{W} . \mathrm{T}}=\frac{(6,11 \cdot 40,116) \cdot(0.238 \cdot 126,879)}{240^{2}}=128,500$

Wamena - Jayapura: $\mathrm{I}_{\mathrm{W} . \mathrm{J}}=\frac{(6,11 \cdot 40,116) \cdot(26,03 \cdot 288,786)}{270^{2}}=25,274,444$

Wamena - Nabire: $\quad I_{\text {W.J }}=\frac{(6,11 \cdot 40,116) \cdot(8,65 \cdot 159,831)}{350^{2}}=2,766,304$

Wamena - Sarmi: $\quad \mathrm{I}_{\mathrm{W} . \mathrm{J}}=\frac{(6,11 \cdot 40,116) \cdot(1,2 \cdot 40,570)}{225^{2}}=235,711$

Figure 2 Results Calculate The Interaction Relationship of Two Cities

\begin{tabular}{|c|c|c|c|c|c|}
\hline No & City & Population & $\begin{array}{c}\text { From } \\
\text { Wamena to } \\
(\mathrm{km})\end{array}$ & $\begin{array}{c}\text { PDRB ADHB } \\
\text { (Billion) }\end{array}$ & $\begin{array}{c}\text { Value of } \\
\text { Interaction }\end{array}$ \\
\hline 1 & Wamena & 40,116 & - & 6.11 & - \\
\hline 2 & Agats & 14,412 & 190 & 1.82 & 178,093 \\
\hline 3 & Timika & 126,879 & 240 & 2.56 & $1,382,181$ \\
\hline
\end{tabular}


Figure 2, cont

\begin{tabular}{|c|c|c|c|c|c|}
\hline 4 & Jayapura & 288,786 & 270 & 26.03 & $25,274,444$ \\
\hline 5 & Nabire & 159,831 & 350 & 8.65 & $2,766,304$ \\
\hline 6 & Sarmi & 40,570 & 225 & 1.32 & 259,282 \\
\hline
\end{tabular}

Source: Calculation

After going through the calculation above, we can conclude that the city with the most interaction is Jayapura. The city has the highest value compared to other cities, such as Agats, Nabire, Timika, and Sarmi. This is due to fact that Jayapura is the capital of the Province of Papua, while the others are only cities or capitals of a district. This means its level of population density and income per capita are higher than other cities. Therefore, the author will create a new transportation line that will be heading to Jayapura from Wamena.

Viewed from the principle of distribution of goods, the interaction of these two cities will produce the right distribution channel for distributing goods and services. Later, the interaction between both cities will result in the distribution of goods that have a direct impact on the price of goods in both cities. Especially for the principles, they will be easier to distribute their goods from Wamena to Jayapura or vice versa. Meanwhile, the consumers will be more convenient in obtaining the goods in their area.

Topographically, the route from Jayapura to Wamena will pass over the mountainous form of terrain. The level of wind speed in the mountainous areas ranges between 41 and $50 \mathrm{~km}$ per hour. The author decided to use the tricable-type cable-car with the expectation that the cablecar will be able to withstand such level of wind speed. Then, the author will use 180 poles in a span of $270 \mathrm{~km}$.

\section{Conclusion}

After conducting this descriptive method reseach, it can be concluded that:

- The two cities that have the best interaction based on Stewart's gravity calculation are the city of Wamena and Jayapura. 
- It is hoped that the cable-car as the alternative mode of transportation will make the price of goods in these two cities reduced and can ease the distribution of goods to/from Wamena and Jayapura.

- The type of cable-car to be used is the tricable-type cable-car. This type of cable-car is chosen because it is expected to be able to withstand wind speed between the two cities where it happens to be a mountainous region and to transport a payload of approximately $400 \mathrm{~kg}$.

Although by using Stewart's method it is obtained that the best interaction is by connecting the city of Jayapura and Wamena, the author suggests that there is a pilot project first for a closer distance with a lower maximum load and easier construction materials obtained in the surrounding area around; for example, the city of Agats. With the abundance of iron wood in the area which later can be used as materials for the cable-car, it can be easier in terms of costs and sources for the construction purposes. This route though only accommodates a little amount of goods, it is still expected to be a pioneer project, which later will be used to ease the transport of materials that is more reliable in developing the cable-car, such as the concrete. Therefore, eventually it can increase the maximum load to be higher.

If we re-examine by looking at areas around Papua, such as Makassar, that are main hubs for distribution of goods to eastern part of Indonesia, then by using Stewart's gravitational the obtained result will be a larger level of interaction to Makassar compared to Jayapura. And, among the areas in Papua which have close proximity with Wamena, such as Jayapura, Nabire, Timika, Agats and Sarmi, the city of Agats is the nearest. With the connection between the city of Agats and Wamena, it will result in lower price of goods compared with connecting the city Wamena and Jayapura.

\section{References}

BPS-Statistics of Mimika Regency. (2014). Kabupaten Mimika Dalam Angka, 53. Retrieved from http://www.mimikakab.go.id/baru/wpcontent/uploads/2015/10/Mimika_Dalam_Angka_2014.pdf\%0Ahttps:// mimikakab.bps.go.id/ 
Christanto, J. (2007). KAJIAN PERKEMBANGAN PERMUKIMAN WILAYAH PERI URBAN DI SEBAGIAN WILAYAH KABUPATEN SUKOHARJO TAHUN 2001-2007 Virta, 1-8.

Doppelmayr. (n.d.). Kereta Gantung di Perkotaan.

Edi, D. W. (n.d.). Biaya Logistik Dan Kelancaran Pengiriman Logistic Costs and the Good' S Delivery, 3(2), 227-243.

Interface, P. C. I. (2011). P PCI transports du quotidien CETE Aerial cableways as urban transport systems, (December).

Kadarisman, M., Gunawan, A., \& Ismiyati, I. (2016). Kebijakan Manajemen Transportasi Darat dan Dampaknya Terhadap Perekonomian Masyarakat di Kota Depok. Jurnal Manajemen Transportasi \& Logistik, 3(1). Retrieved from http://www.ejournal.stmttrisakti.ac.id/index.php/JMTRANSLOG/article/view/72

Kuncoro, A. W. (2011). ANALISIS SEKTOR EKONOMI POTENSIAL DAN INTERAKSI WILAYAH KOTA CILEGON TAHUN 20072011 Oleh :, 1-12.

Pengguna, K., Transportasi, J., Loyalitas, U. M., Saribanon, E., Tinggi, S., Trisakti, M. T., ... Trisakti, T. (2016). Kepuasan Pengguna Jasa Transportasi Untuk Meningkatkan Loyalitas the Satisfaction of Transportation'S Customers To Enchance Loyalty. Jurnal Manajemen Transportasi \& Logistik, 3(3), 317-326.

Robinson, T. (2005). Perencanaan Pembangunan Wilayah. Sinar Grafika Offset. Jakarta, 1-40.

S, T. I. H. (n.d.). MULTIMODA DALAM MEWUJUDKAN VISI LOGISTIK INDONESIA 2025, 69-84.

Sitorus, B., \& Sitorus, C. N. (n.d.). Pengembangan sektor transportasi untuk meningkatkan aksesibilitas kabupaten pulang pisau, 353-371.

Sitorus, C. N., Nasional, U. P., Sitorus, B., \& Kementerian, S. J. (n.d.). PENGEMBANGAN INFRASTRUKTUR TRANSPORTASI DI PROVINSI NUSA TENGGARA TIMUR THE DEVELOPMENT OF TRANSPORT, 4(2), 203-210.

Statistik, B. P. (n.d.). KECAMATAN WAMENA DALAM ANGKA 2017.

Statistik, B. P., \& Asmat, K. (2016). Distrik Agats dalam angka 2016.

Tezak, S., Sever, D., \& Lep, M. (2016). Increasing the Capacities of Cable Cars for Use in Public Transport. Journal of Public Transportation, 19(1), 1-16. https://doi.org/10.5038/2375-0901.19.1.1 